\title{
Use of grossularia robusta gooseberry species in breeding
}

\author{
Oleg Kurashev*, and Yulia Titova \\ Russian Research Institute of Fruit Crop Breeding (VNIISPK), 302530 Orel, Russian Federation
}

\begin{abstract}
Gooseberry is a valuable small-fruit crop. The All-Russian Research Institute of Fruit Crop Breeding (Russia) has been carrying out the breeding work on gooseberries since 1993. The article presents usage data of distant hybridization (interspecies crossbreeding) of gooseberry selection with the Grossularia robusta species. This species is characterized as a valuable traits' donor for obtaining hybrids resistant to American mildew and leaf spotting, as well as weak acicularity and compact bush habitus. Since 2001, we have actively involved this species in breeding. As a result, selected seedlings have been selected from the offspring of distant hybrids with the participation of Grossularia robusta species; these seedlings have the optimal complex of economic traits - resistance to American mildew and leaf spotting damage, sufficient fruit weight and satisfactory parameters of physical and mechanical properties of berries, weak acicularity, compact bush habitus. The obtained selected forms have a set of qualities that are necessary according to the conditions and requirements of mechanized harvesting.
\end{abstract}

\section{Introduction}

Gooseberry is a valuable small-fruit crop that is very popular with private producers and undeservedly ignored as a very profitable and promising industrial small-fruit crop. Moreover, at present, gooseberry crop is practiced on very limited areas even in the developed agrarian regions of Europe. So, according to Plut [1], the main commercial producers of gooseberries are Poland, Hungary, Czech Republic, Slovakia and the Baltic States. However, along with other commercial small-fruit crops, gooseberry takes an unfortunate place of an outsider. The reason for this is the difficulty of reproduction on a sufficient scale, the absence of varieties that optimally combine a number of economic traits in one genome and phenotype. In particular, there is a large shortage of varieties with a complex of often mutually exclusive traits: yield-fruit weight, no acicularity (weak acicularity) - taste of fruits, acicularity-fruit weight-disease resistance. Due to correlation relations and connections, excretion of one trait to the optimal level entails a drop in the phenotypic expression of another trait. This represents the main difficulty in carrying out breeding work with this crop.

For the gooseberries' introduction into a line of promising industrial berry crops, it is required to create varieties suitable for intensive cultivation and, in particular, suitable for

\footnotetext{
* Corresponding author: kurashev@vniispk.ru
} 
mechanized harvesting. Gooseberries' manual harvesting presents the greatest difficulties, especially in fairly and strongly acicular varieties. Therefore, harvesting is one of the most time-consuming operations in the complex of gooseberries' cultivation and must be carried out using various kinds of mechanisms (berry harvesters). Foreign and domestic researchers [2-8] dealt with the issues of gooseberries' mechanized harvesting and have achieved certain success in this direction. However, it should be noted that the matters of mechanized harvesting of small-fruit crops and particularly gooseberries require tandem efforts cooperation of both harvesting equipment designers and breeders, who should create varieties with parameters suitable for harvesting.

Currently, the existing gooseberry crop range has varieties that are resistant and highly resistant to American mildew (AM), and according to some data - even immune to this pathogen, for example, the swedish variety Jakob [9]. At the same time, one of the methods of creating highly AM and leaf spotting resistant gooseberry varieties and forms is distant hybridization with species acting as resistance sources to these pathogens. A great contribution to understanding the principles of remote cross-breeding and the creation of interspecies hybrids in the Ribes family belongs to E. Keep [10]. Also a lot of work on attracting wild species in gooseberry selection was carried out by a number of domestic scientists [11-16]. So, in the research on remote hybridization by K. D. Sergeeva, G. robusta was used in breeding for high resistance to AM and leaf spotting among other species. However, as the author points out, obtained offspring had mainly small fruits and that further saturation or back cross-breeding (backcrosses) were required to eliminate this shortcoming $[15,17]$.

The All-Russian Research Institute of Fruit Crop Breeding (VNIISPK, Orel) has been carrying out gooseberries' breeding since 1993 to the present time. During this period, selected forms, complex sources and valuable traits' donors, promising elite seedlings were received, and 6 new gooseberry varieties were transferred to variety testing [18]. Since 2001, the Institute has carried out systematic and large-scale breeding work using Grossularia robusta species in hybridization as one of the parents for obtaining forms that optimally meet the requirements of mechanized harvesting - primarily, resistance to AM and leaf spotting, as well as with the optimal complex of economic traits $[19,20]$. The attraction of the Grossularia robusta species in breeding was due to its high resistance to AM damage of fruits and vegetative organs. At the same time, this species also has such economic traits as compact bush habitus, high winter survival and general adaptability to bio- and abiotic environmental factors with well transmittion of these traits to offspring.

The aim of the research was to create distant interspecies hybrids with a valuable economic traits' complex, primarily high resistance to AM damage and leaf spotting, sufficient fruit weight, optimal physical and mechanical properties of berries, weak acicularity, compact bush habitus - that is, with those parameters that are required for mechanized harvesting conditions.

\section{Materials and methods}

Hybridization, selections and basic records were carried out at the experimental breeding sites of the All-Russian Research Institute of Fruit Crop Breeding (VNIISPK) (Orel). The institute is located in the European part of Russia southwest of Moscow $\left(53^{\circ} 00^{\prime} \mathrm{N}, 36^{\circ} 00^{\prime} \mathrm{E}\right)$ in the suburban area. Experimental site soils - gray and dark gray forest, lighlty and fairly podzolized, medium-loamy mechanical composition with 4.6-5.0 $\mathrm{pH}$.

In all combinations of distant crossbreeding, Grossularia robusta species was used as the male parent; promising selected and elite forms of gooseberry bred by VNIISPK were used as female parents. Castration, pollination of castrated flowers and isolation (protection against uncontrolled penetration of entomophils with foreign pollen to pollinated flowers), 
as well as subsequent production of hybrid seedlings, basic accounting and selection of promising seedlings from hybrid families were carried out according to the methodical recommendations of "Program and methodology of variety study of fruit, berry and nut crops [21]. The fruits' detachment force was determined using "Dina-2" device; the crushing effort - using "Plodtest-1" (produced by SibFTI SFNCA RAS according to TC 4381-002-05030170-2010, Novosibirsk). The obtained seedlings from hybrid families and selected forms were planted on the site of primary strain investigation with a distance of 0.5 $\mathrm{m}$ in a row and $3.5 \mathrm{~m}$ in the interrow. Plants were grown with artificial drip irrigation. For registration correctness of experimental plants' damage degree by American mildew (Sphaerotheca mors-uvae Berk. Et Curt.) and leaf spotting (septoriosis - Septoria ribis Desm. and anthracnose - Pseudopeziza ribis Kleb.), no protective measures were carried out on the experimental site. Resistance assessment was carried out at the maximum severity of the disease.

Statistical processing of experimental data was carried out using the computer program "Excel".

\section{Results and discussion}

Since 2001, VNIISPK has carried out extensive work to obtain gooseberry forms resistant to such dangerous phytopathogens as American mildew (Sphaerotheca mors-uvae Berk. Et Curt.) and leaf spotting (Septoria ribis Desm. and Pseudopeziza ribis Kleb.). For this purpose, Grossularia robusta gooseberry species was attracted in crossbreeding as a male parent. According to many years of our observations between 1995 and 2020, there was no precedent for $G$. robusta species damage with AM and leaf spotting (with no damage of both generative and vegetative organs). Brief economic and biological characteristics of selected gooseberry seedlings obtained from distant crossbreeding with the participation of the $G$. robusta species is presentedin table 1 .

Table 1. Economic and biological characteristics of selected gooseberry hybrids obtained from distant crossbreeding with the participation of theG. Robusta species (2019-2020)

\begin{tabular}{|c|c|c|c|c|c|c|}
\hline \multirow[b]{2}{*}{$\begin{array}{c}\text { Hybrid } \\
\text { seedlings }\end{array}$} & \multirow{2}{*}{$\begin{array}{c}\text { Hybri } \\
\text { d } \\
\text { family } \\
\text { (origin) }\end{array}$} & \multirow[b]{2}{*}{ Acicularity } & \multirow{2}{*}{$\begin{array}{c}\text { Avera } \\
\text { ge } \\
\text { berry } \\
\text { weigh } \\
\text { t, } \mathbf{g}\end{array}$} & \multirow{2}{*}{$\begin{array}{c}\text { Maximu } \\
\text { m berry } \\
\text { weight, } g\end{array}$} & \multicolumn{2}{|c|}{$\begin{array}{c}\text { Damage by } \\
\text { diseases, score }\end{array}$} \\
\hline & & & & & $\begin{array}{c}\text { AM } \\
\text { (fruits/ } \\
\text { leaves) }\end{array}$ & $\begin{array}{c}\text { Leaf } \\
\text { spotting }\end{array}$ \\
\hline $8-288(2)-1$ & $\begin{array}{l}\text { 151-HC-7 } \\
\times G . \\
\text { robusta }\end{array}$ & barely acicular & 1.9 & 2.0 & $0 / 0$ & 0.5 \\
\hline $8-288(2)-2$ & $-*_{-}$ & barely acicular & 0.8 & 1.3 & $0 / 0$ & 0.5 \\
\hline $8-288(2)-2(1)$ & $-*$ & fairly acicular & 2.0 & 3.0 & $0 / 0$ & 0.5 \\
\hline $8-288(2)-3$ & $-*_{-}$ & fairly acicular & 0.6 & 1.5 & $0.5 / 0.5$ & 0.5 \\
\hline $8-288(2)-15$ & $-*$ & barely acicular & 0.9 & 1.5 & 0 & 0.5 \\
\hline $8-288(2)-18$ & $-*_{-}$ & barely acicular & 1.4 & 2.6 & 0 & 0.5 \\
\hline $8-288(2)-19$ & $-*_{-}$ & strongly acicular & 1.7 & 2.6 & 0 & 0.5 \\
\hline $9-283(2)-1$ & $\begin{array}{l}142-\times 36- \\
12 \times G \\
\text { robusta }\end{array}$ & totally non-acicular & 0.9 & 2.0 & 0 & 0.5 \\
\hline $9-283(2)-1(2)$ & $-*_{-}$ & barely acicular & 2.1 & 3.8 & $0.5 / 0.5$ & 0.5 \\
\hline $9-283(2)-1(3)$ & $-*$ & strongly acicular & 1.5 & 2.8 & 0 & 0.5 \\
\hline $9-283(2)-1(4)$ & $-*$ & fairly acicular & 1.4 & 2.8 & 0 & 0.5 \\
\hline $9-283(2)-1(5)$ & $-*$ & fairly acicular & 2.0 & 3.6 & 0 & 0.5 \\
\hline $9-283(2)-1(6)$ & $-*_{-}$ & barely acicular & 2.1 & 3.8 & 0 & 0.5 \\
\hline $9-283(2)-1(7)$ & $-*_{-}$ & barely acicular & 1.5 & 3.0 & 0 & 0.5 \\
\hline $9-283(2)-2$ & $-*_{-}$ & fairly acicular & 2.2 & 3.7 & 0 & 0.5 \\
\hline $9-283(2)-2(1)$ & $-*$ & barely acicular & 1.8 & 3.0 & 0 & 0.5 \\
\hline
\end{tabular}




\begin{tabular}{|l|l|l|l|l|l|l|}
\hline $9-283(2)-2(2)$ & $-*_{-}$ & barely acicular & 1.7 & 3.6 & 0 & 0.5 \\
\hline $9-283(2)-2(3)$ & $-*_{-}$ & barely acicular & 1.8 & 3.2 & 0 & 0.5 \\
\hline $9-258(2)-2$ & $\begin{array}{c}13-15-1 \times \\
\text { G. robusta }\end{array}$ & barely acicular & 2.1 & 3.7 & 0 & 0.5 \\
\hline $9-258(2)-4$ & $-*_{-}$ & barely acicular & 1.2 & 2.1 & 0 & 0.5 \\
\hline $9-258(2)-8(1)$ & $-*_{-}$ & barely acicular & 1.1 & 1.8 & 0 & 0.5 \\
\hline $9-258(2)-9(1)$ & $-*_{-}$ & fairly acicular & 1.7 & 2.4 & 0 & 0.5 \\
\hline $9-258(2)-12$ & $-*_{-}$ & barely acicular & 1.4 & 2.7 & 0 & 0.5 \\
\hline $9-258(2)-13$ & $-*_{-}$ & barely acicular & 1.6 & 3.1 & 0 & 0.5 \\
\hline $9-258(2)-14$ & $-*_{-}$ & barely acicular & 1.1 & 1.9 & 0 & 0.5 \\
\hline $9-258(2)-16$ & $-*_{-}$ & barely acicular & 1.3 & 2.5 & 0 & 0.5 \\
\hline $\begin{array}{l}9-258(2)- \\
16(1)\end{array}$ & $-*_{-}$ & barely acicular & 1.5 & 3.3 & 0 & 0.5 \\
\hline $\begin{array}{l}9-258(2)- \\
16(2)\end{array}$ & $-*_{-}$ & barely acicular & 1,4 & 2.3 & 0 & 0.5 \\
\hline $9-258(2)-17$ & $-*_{-}$ & barely acicular & 1,1 & 1.6 & 0 & 0.5 \\
\hline $\begin{array}{l}9-258(2)- \\
17(1)\end{array}$ & $-*_{-}$ & barely acicular & 1.2 & 2.0 & 0 & 0.5 \\
\hline $\begin{array}{l}9-258(2)- \\
17(2)\end{array}$ & $-*_{-}$ & barely acicular & 1.3 & 2.6 & 0 & 0.5 \\
\hline $\begin{array}{l}9-258(2)- \\
19(1)\end{array}$ & $-*_{-}$ & barely acicular & 1.4 & 2.5 & 0 & 0.5 \\
\hline $9-258(2)-24$ & $-*_{-}$ & fairly acicular & 1.6 & 2.7 & 0 & 0.5 \\
\hline $9-258(2)-25$ & $-*_{-}$ & barely acicular & 1.5 & 2.4 & 0 & 0.5 \\
\hline $\begin{array}{l}9-258(2)- \\
26(1)\end{array}$ & $-*_{-}$ & barely acicular & 1.6 & 2.8 & 0 & 0.5 \\
\hline V, \% & & & 26.54 & 26.64 & & \\
\hline
\end{tabular}

According to the observations, almost all seedlings from hybrid families obtained from distant crossbreeding with the G. robusta species had no observed damage by AM neither on fruits nor vegetative organs. Only single seedlings in two hybrid families showed signs of AM damage to berries and upper parts of shoots up to 0.5 points. Leaf damage with anthracnose and septoriosis in all families did not exceed 0.5 points. In general, seedlings of all hybrid families had small average fruit weight - 1.5-2.0 g (patroclinal influence of $G$. robusta male parent, its maximum fruit weight does not exceed $0.7 \mathrm{~g}$ ). However, within each family, selected seedlings with a maximum weight of up to $4.0 \mathrm{~g}$ were noted. It was also noted that the use of the G. robusta species in breeding allows to obtain numerous offspring with minimal manifestation of acicularity trait. Thus, in the family 283 (142-x36$12 \times$ G. robusta), an acicularity-free seedling 9-283 (2) -1 was obtained, which had an absolute absence of spines in the nodes and spinelets in the internodes both on perennial wood and on annual growth. In general, the three families analyzed showed the prevalence of selected seedlings with a pronounced phenotypic effect of weak shoots' acicularity.

For gooseberries' varieties and forms corresponding to the mechanized harvesting conditions, such limiting parameter as physical and mechanical properties of fruits (detachment force and crushing force) and such unlimiting trait as the general bush architectonics (habitus) are of importance. The selected gooseberry forms obtained from distant crossbreeds involving the G. robusta species had a number of optimal parameters required for mechanized harvesting conditions. Thus, the fruits' detachment force in the studied forms varied (min-max) in the range from $174 \mathrm{~g}$ in the selected seedling 8-288 (2) 15 to $341 \mathrm{~g}$ in the seedling 9-258 (2) -9 (1), while average detachment force values ranged from $220 \mathrm{~g}$ to $250 \mathrm{~g}$ (Fig. 1). As can be seen in the graph, this indicator is subject to a significant variation depending on the growing season's conditions. It should also be pointed out that other authors' similar studies on detachment force and crushing force in a number of European gooseberry varieties showed rather different values. So, according to data of Sorokopudov V. N. et al. [8], in 20 studied varieties of domestic and foreign breeding, the fruits' detachment force fluctuated in 87-182 $\mathrm{N}$ range, and the crushing force 
varied from $417 \mathrm{~N}$ to $693 \mathrm{~N}$. As can be seen, in distant hybrids, the indicators of these two parameters exceed the same of European type varieties.

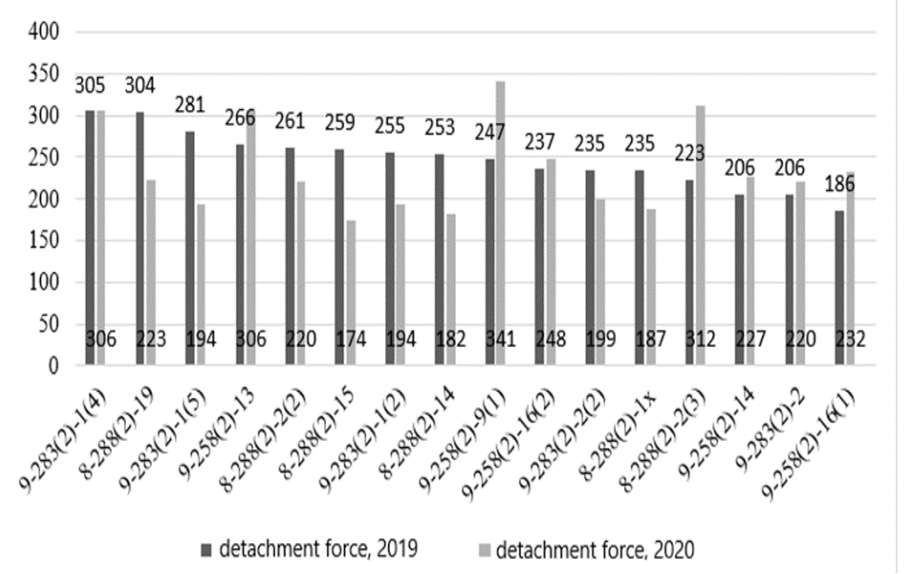

Fig. 1. Physical and mechanical properties of selected gooseberry forms obtained from distant crossbreeding with $\mathrm{G}$. Robusta variety

The crushing force limiting parameter in the studied selected forms ranged from $644 \mathrm{~g}$ in the selected seedling 8-288 (2) -15 to 2039 g in the seedling 9-283 (2) -1 (4) (Fig. 2), which fits into the scheme of required minimum crushing force for mechanized harvesting conditions (> $200 \mathrm{~g}$ ) [17]. Most likely, indicators of the fruits' detachment force and their relative strength (crushing force) are the phenotypic expression of genetic determinants of either oligogenic or, more correctly, polygenic nature. Evidence of this is the varying degree of phenotypic expression; as with the detachment force limiting parameter, the indicator of fruits' crushing force also differs in years and, in a certain way, depends on the conditions of the growing season and the harvest timing.

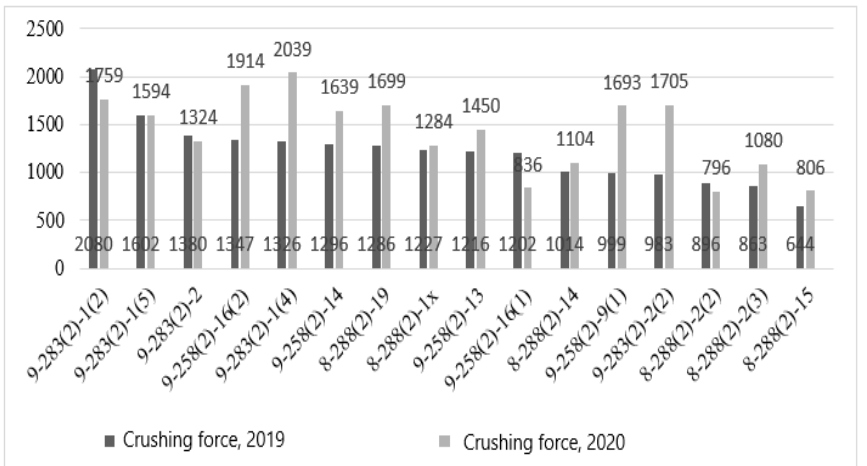

Fig. 2. Physical and mechanical properties of selected gooseberry forms obtained from distant crossbreeding with G. Robusta variety

Examination of such an unlimiting parameter as bush habitus showed that the predominant number of selected seedlings derived from distant crossbreeds involving $G$. robusta species was characterized by optimal bush architectonics - compressed, compact, with orthotropic growth type and placement of the main fruiting zone within the limits required under the conditions of mechanized harvesting [17]. The width of the bush base in the studied forms ranged from 15 to $35 \mathrm{~cm}$, diameter - from 45 to $125 \mathrm{~cm}$, the bush height - 
from 105 to $180 \mathrm{~cm}$ (Fig. 3). At the same time, even under considerable yield load, branches of the studied forms continued to maintain an orthotropic position, the bushes practically did not fall apart and had a compact habitus.

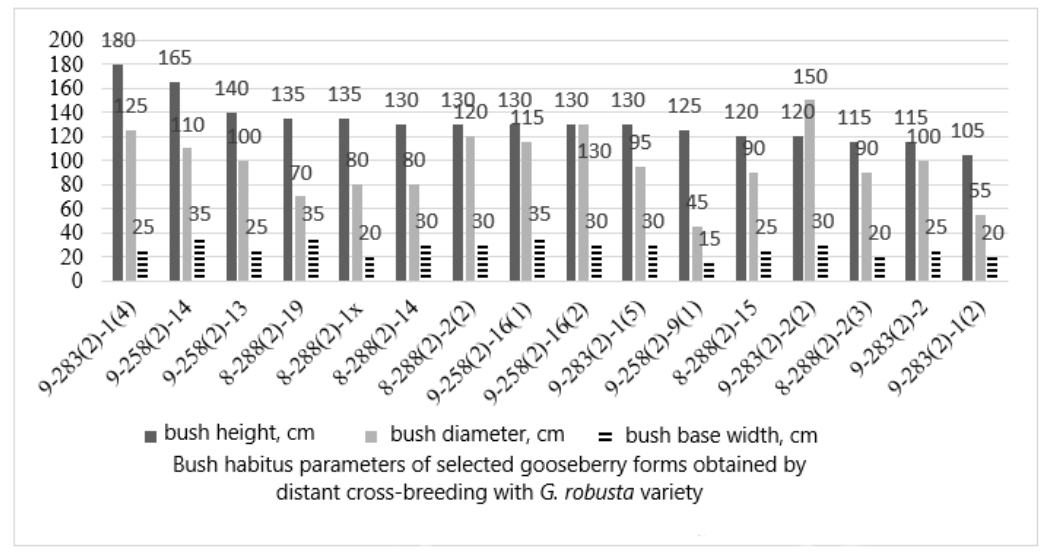

Fig. 3. Shows the significant excess in fruit weight achieved in some selected forms obtained from distant crossbreeding in comparison with the male parent - G. Robusta species.

At the same time, it should be noted that G. robusta species fruiting is characterized by multiple clusters, i.e. one node may have several 2-3-fruit clusters. Among the selected forms obtained from distant crossbreeding involving the G. robustaspecies, we also found seedlings with multiple clusters fruiting type (which is not typical for most varieties and hybrids previously obtained with $G$. reclinata species); with this, there was a transgressive nature of this trait's phenotypic expression. Even with a small fruit weight typical for the prevailing number of selected forms of distant hybrids, this type of fruiting (multiple clusters) causes a large load of crop (up to $8-9 \mathrm{~kg} / \mathrm{bush}$ !).

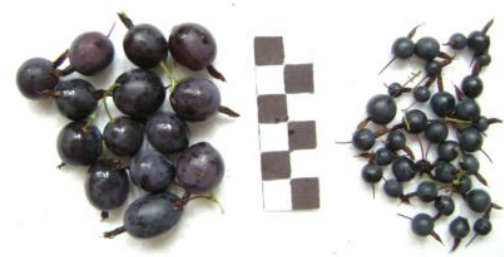

Fig. 4. Fruit of selected seedling 9-283 (2)-1(2) (142-x36-12 $\times$ G. Robusta) max fruit weight $3.8 \mathrm{~g}$ (right - G. robusta fruits, max weight $0,7 \mathrm{~g}$ )

\section{Conclusion}

Attraction of $G$. robusta gooseberry species in breeding research allowed to obtain distant hybrid offspring possessing many valuable economic traits. Selected seedlings are characterized by resistance to the most harmful diseases - American mildew ( 0 points damage), leaf spotting ( 0.5 points damage), sufficient fruit weight (with a maximum value of up to 3-4 g), weak shoots' acicularity, optimal indicators of fruits' physico-mechanical properties (detachment force - 150-200 g, crushing force - over $200 \mathrm{~g}$ ). Also, selected 
seedlings have a straight, weakly sprawling bush habitus. Our research has established that the attraction of $G$ robusta species as a donor of valuable traits allows to purposefully obtain promising breeding forms for subsequent breeding of new "industrial" type gooseberry varieties, including the ones suitable for mechanized harvesting.

\section{References}

1. S. Pluta, Acta Horticulturae, 946, 27 (2012)

2. J. V. Christensen, Proc. Balsgard Fruit Brdg Symp, 90 (1966)

3. E. Yu. Koveshnikova, Herald of MichSAU, 3, 80 (2012)

4. V. G. Tolstoguzova, Fruit growing and berry growing of Russia, 22(2), 311 (2009)

5. U. A Utkov, V. V. Bychkov, G. I. Kadykalo, Fruit growing and berry growing of Russia, 25, 299 (2010)

6. N. S. Krayushkina, K. I. Egorova, Technologies and technical means of mechanized production of crop and livestock products, 97, 176 (2018)

7. G. P. Atroshchenko, N. A. Pupkova, K. A. Volkova, Proceedings of the international scientific-practical conference, 115, 113 (2019)

8. V. N. Sorokopudov, S. V. Kalugina, N. S. Kuharuk, M. V. Yevtukhova, Yu. Yu. Ivanova, Herald of KrasSAU, 4, 80 (2020)

9. V. L. Vitkovsky, Fruit Plants of the World, 346 (2003)

10. E. Keep, Genetica, 33(1), 1 (1963)

11. A. B. Viksne, Coll. of scientific works of the All-Russian Research Institute of Horticulture named after I. V. Michurin, 21, 122 (1975)

12. E. K. Kirtbaya, Coll. of scientific works of the All-Russian Research Institute of Horticulture named after I. V. Michurin, 21, 108 (1975)

13. E. P. Kuminov, Coll. of scientific works of the All-Russian Research Institute of Horticulture named after I. V. Michurin, 21, 153 (1975)

14. I. V. Popova, Coll. of scientific works of the All-Russian Research Institute of Horticulture named after I. V. Michurin, 21, 101 (1975)

15. K. D. Sergeeva, Gooseberry, 208 (1989)

16. I. G. Tyunikov, Coll. of scientific works of the All-Russian Research Institute of Horticulture named after I. V. Michurin, 21, 159 (1975)

17. K. D. Sergeeva, Coll. of scientific works of the All-Russian Research Institute of Horticulture named after I. V. Michurin, 21, 89 (1975)

18. O. Golyaeva, O. Kurashev, S. Knyazev, A. Bakhotskaya, Herald of the Russian Agricultural Science, 4, 41 (2020)

19. O. V. Kurashev, Herald of the Russian Agricultural Science, 6, 58 (2018)

20. O. V. Kurashev, S. D. Knyazev, Yu. G. Titova, Herald of the Kursk State Agricultural Academy, 7, 76 (2019)

21. S. D. Knyazev, L. V. Bayanova, Program and methods of variety study of fruit, berry and nut crops, 351 (1999) 